\title{
The efficacy of locoregional radiotherapy plus chemotherapy vs. chemotherapy alone in metastatic nasopharyngeal carcinoma: a meta-analysis
}

\author{
Guoxiang Wang, Liangfang Shen \\ Department of Oncology, Xiangya Hospital, Central South University, Changsha, China \\ Contributions: (I) Conception and design: G Wang; (II) Administrative support: L Shen; (III) Provision of study materials or patients: L Shen; (IV) \\ Collection and assembly of data: G Wang; (V) Data analysis and interpretation: G Wang; (VI) Manuscript writing: All authors; (VII) Final approval \\ of manuscript: All authors. \\ Correspondence to: Professor Liangfang Shen. Department of Oncology, Xiangya Hospital, Central South University, No. 87, Xiangya Road, Changsha \\ 410008, China. Email: 1fshen2008@163.com.
}

\begin{abstract}
Background: The role of locoregional radiotherapy (LRT) of the nasopharynx and neck in patients with metastatic nasopharyngeal carcinoma (M-NPC) remains unclear. The present meta-analysis aimed to compare the efficacy of chemotherapy (CT) plus LRT with CT alone in M-NPC patients.

Methods: Eligible manuscripts were searched in the following electronic databases: Cochrane Library, Embase, and PubMed. The hazard ratio (HR) of overall survival (OS) and progression-free survival (PFS), and the risk ratio (RR) of the objective response rate (ORR) and disease control rate (DCR) were pooled and expressed with the $95 \%$ confidence intervals (CIs). The analysis was conducted using Review Manager and Stata software.

Results: In total 15 retrospective studies and 1 randomized controlled trial were identified comparing 3,402 M-NPC patients of whom 1,387 received CT alone and 2,015 were treated with CT plus LRT. The adjusted HR of OS for CT plus LRT compared with CT alone was 0.45 (95\% CI: 0.40-0.52), while the pooled HR of PFS was 0.37 (95\% CI: 0.29-0.49). The pooled RR of ORR and DCR for CT plus LRT compared with CT alone was 0.60 (95\% CI: 0.46-0.79) and 0.77 (95\% CI: 0.71-0.85), respectively. Heterogeneity or publication bias in the studies was not found to have altered the conclusion.

Conclusions: For patients with M-NPC, CT + LRT is superior to CT alone providing the higher OS, PFS, ORR, and DCR compared with CT alone. CT combined with LRT should be recommended as a more suitable choice for M-NPC patients.
\end{abstract}

Keywords: Nasopharyngeal carcinoma (NPC); metastatic; chemotherapy; locoregional radiotherapy (LRT)

Submitted Aug 06, 2020. Accepted for publication Dec 01, 2020.

doi: 10.21037/apm-20-1561

View this article at: http://dx.doi.org/10.21037/apm-20-1561

\section{Introduction}

Metastasis is a major reason for the treatment failure of treatments in nasopharyngeal carcinoma (NPC) (1). In general, $80-90 \%$ patients with non-metastatic NPC could achieve 5-year overall survival (OS) if treated with locoregional radiotherapy (LRT) of the nasopharynx and neck combined with systemic chemotherapy (CT) $(2,3)$. Every year, more than 80,000 patients are diagnosed with
NPC (4), of whom 4-10\% patients have metastatic lesions $(5,6)$. Additionally, metastatic lesions occur in $15-30 \%$ of NPC patients after receiving initial treatment received $(5,6)$. Once an NPC tumor has metastasized, not only has the opportunity for radical treatment been missed, patients have a very poor prognosis with a median OS of only 20 months (7). Aiming to provide the most effective cure for metastatic nasopharyngeal carcinoma (M-NPC), a variety 
of treatments including systemic chemotherapy, LRT, local treatment of metastatic lesions, targeted treatment and immunotherapy, have been utilized over the past decade (8-10). However, the national comprehensive cancer network (NCCN) guidelines only recommend systemic chemotherapy, consisting principally of a platinum-based combination regimen as the primary choice for M-NPC (11). Due to a lack of good evidence, LRT and other treatments can only be recommended as a secondary choice, or administered in the context of a clinical trial (11). Nevertheless, clinicians tend to use LRT as part of the primary treatment for M-NPC by combining it with systemic chemotherapy. This treatment modality may be supported by retrospective studies of the prognosis of patients with M-NPC.

Two recent publications extracted data for M-NPC patients from the Surveillance Epidemiology and End Results (SEER) database and the National Cancer Database (NCDB), concluding that CT combined with LRT does prolong the OS of M-NPC patients $(12,13)$. Additionally, You and his colleagues introduced the first randomized controlled trial (RCT) to compare the efficacy of CT plus LRT with CT alone in newly diagnosed M-NPC patients (14). In that clinical trial, the rate of 2 -year OS for CT alone group and CT combine with LRT were $54.5 \%$ and $76.4 \%$, respectively (HR 0.42, 95\% CI: $0.23-0.77, \mathrm{P}=0.004)$. Thus, the present meta-analysis aimed to combine all available data to determine the efficacy of LRT in treating M-NPC by comparing LRT plus CT and CT alone, and supplement current evidence for the benefit of evidence-based medicine.

We present the following article in accordance with the PRISMA reporting checklist (available at http://dx.doi. org/10.21037/apm-20-1561).

\section{Methods}

\section{Literature search strategy}

All articles were searched in the Cochrane library, Embase, and PubMed and from the published data of these electronic databases (the deadline was $4^{\text {th }}$ August, 2020). The advanced search was used and the specific strategy was: ('nasopharynx cancer' OR 'nasopharyngeal carcinoma') AND (metastatic OR M1) AND (chemoradiotherapy OR chemotherapy OR radiotherapy). The fields of search were title and abstract, while the language was English or Chinese. There was no restriction on time of publication.

\section{Inclusion and exclusion criteria}

Studies were included if they met the following criteria: (I) patients: histological or cytological diagnosed NPC, pathologically confirmed or radiographic confirmed metastatic lesions(including initial metastases and first relapse metastases), aged 18 years or older; (II) therapeutic intervention: platinum-based first-line chemotherapy plus LRT; (III) control: platinum-based first-line chemotherapy alone; (IV) outcome: at least one available outcome about efficacy of treatment, including objective response rate (ORR), disease control rate (DCR), progression-free survival (PFS), OS, and hazard ratio (HR) and $95 \%$ confidence interval (CI) of HR; (V) study design: randomized controlled trials or retrospective studies. Exclusion criteria were: (I) recurrent NPC without metastatic lesion; (II) received targeted therapy, immunotherapy, or other systemic treatment; (III) unpublished studies; (IV) single arm clinical trials.

\section{Data extraction and quality assessment}

By browsing title and abstract of potential literature, the literatures unrelated to our objective were excluded. Then the eligible studies that both met inclusion and exclusion criteria were included through read full text in detail. Data was extraction from final included studies and recorded in the pre-designed table, which contains first author, year of publication, study design, inclusion period, follow-up, number of patients, therapeutic intervention and original outcomes.

Retrospective studies were assessed by methodological index for non-randomized studies (MINORS), which was recommended for assessing non-randomized interventional studies (15). MINORS consists of 12 items: a clearly stated aim, Inclusion of consecutive patients, prospective collection of data, endpoints appropriate to the aim of the study, unbiased assessment of the study endpoint, followup period appropriate to the aim of the study, loss to follow up less than $5 \%$, prospective calculation of the study size, an adequate control group, contemporary groups, baseline equivalence of group, adequate statistical analyses (16). And each item was scored 0 (not reported), 1 (reported but inadequate) or 2 (reported and adequate). Studies with scores $\geq 16$ were regard as high-quality, while studies with scores $<16$ and $\geq 8$ were regard as medium-quality. As to RCTs, they were assessed with the Cochrane risk of bias 
assessment tool and assessed from 6 domains: allocation concealment, random sequence generation, blinding, outcome data, selective outcome report and other bias (17). Two reviewers (Wang and Shen) independently extracted and assessed the included literature, and disagreements were resolved by consensus.

\section{Data synthesis and statistical analysis}

In meta-analysis, the efficacy of LRT was evaluated by calculating pooled HR for OS and PFS via survival analysis, and pooled RR of ORR and DCR. For ORR and DCR analysis, the number of each group were used as outcome measures. While in survival analysis to get pooled HR, the specific HR and associated 95\% CI were needed. When HR and associated $95 \%$ CI were unavailable, we used relevant rate of OS and PFS, number of patients of observation group and controlled group, and Kaplan-Meier curves to calculate the HR and variance of $\operatorname{In}(\mathrm{HR})$ (18). Specifically, the formula to get the variance of $\operatorname{In}(\mathrm{HR})$ was: (observed events research $\times$ observed events control)/total events. For example, the patients received LRT and CT were regards as research group, the number of patients who were still alive at $36^{\text {th }}$ month was the 'observed events research'. Likewise, 'observed events control' could be obtained. The 'total events' was the total number of recruited patients. Finally, the variance of $\operatorname{In}(\mathrm{HR})$ at $36^{\text {th }}$ month could be calculated.

Heterogeneity of identified studies was judged by using the $\mathrm{Chi}^{2}$ test and $\mathrm{I}^{2}$ statistical value. If the $\mathrm{P}$ value of the $\mathrm{Chi}^{2}$ test was $<0.10$ or $\mathrm{I}^{2}$ statistical value was $>50 \%$, heterogeneity was considered statistically significant. If heterogeneity existed, we chose random-effects model as the analysis model; if not, the fixed-effects model was chose (19). To eliminate heterogeneity or find out the source of heterogeneity, removing literature stepwise (sensitivity analysis) and subgroup analysis were applied. And to conduct survival analysis in meta-analysis, we entered HR data by using the inverse variance method. In subgroup analysis, the difference of different subgroups was estimated by comparing the pooled HRs of subgroups and test for subgroup differences, which was produced by using Review Manager 5.3 (Cochrane Collaboration, Oxford, UK). If the $95 \%$ CI of HR of two subgroups overlapped, or the value of $\mathrm{P}$-interaction of the test for subgroup differences was more than 0.05 , no significant difference existed in these two subgroups. The meta-analysis mentioned above, including efficacy analysis (pooled HR of PFS and OS, pooled RR of ORR and DCR), sensitivity analysis, drawing forest plots and subgroup analysis, was conducted by using Review Manager. In addition, funnel plot and Egger's test were generated to detect potential publication bias, which were evaluated by Stata software 15.0 (StataCorp., College Station, TX, USA), and $\mathrm{P}$ value of bias $>0.05$ was considered the absent of potential publication bias.

\section{Results}

\section{Characteristics of included studies}

In addition to the RCT mentioned in the Introduction (14), 15 studies were finally selected for inclusion into this metaanalysis (20-34). A flow diagram describing the inclusion and exclusion of studies was presented in Figure 1. The RCT of You et al. (14), registered as NCT02111460, provided available data about HR of OS and PFS. Of the other studies included in the analysis, 3 were case-controlled studies $(27,28,33)$, and 12 were retrospective cohort studies. Only the 3 case-controlled studies conducted an analysis of ORR and DCR. Four studies provided sufficient data to provide a calculation of pooled HR of PFS $(23-25,27)$, two of which provided HR and variance of $\operatorname{In}(\mathrm{HR})$, as calculated by statistical methods $(25,27)$. Except for the study of $\mathrm{Gu}$ et al. (23), it was possible to analyze the pooled HR of OS in the other 15 included studies, while in 4 studies the HR and variance of $\operatorname{In}(\mathrm{HR})$ had to be calculated using statistical methods $(27,28,32,34)$. The baseline characteristics of the studies included in the review were presented in Table 1. In total, 3,402 M-NPC patients were included, of whom 1,387 patients received CT alone and 2,015 patients received CT combine with LRT.

\section{Literature quality evaluation}

Assessed by the Cochrane risk of bias assessment tool, four domains (allocation concealment, blinding, outcome data and selective outcome report) in the RCT of You et al. (14) were judged low risk, while the other two domains (random sequence generation and other bias) were judged unclear risk, because the detail of random sequence generation wasn't described clearly. Apart from the study of You in 2020, the retrospective studies were assessed using MINORS tool. An assessment of the 15 studies was displayed in Table S1. The median follow-up duration of 6 studies were less than 36 months (the item 'follow-up period appropriate to the aim of the study' was scored 1) and the median follow-up duration of other 5 studies 


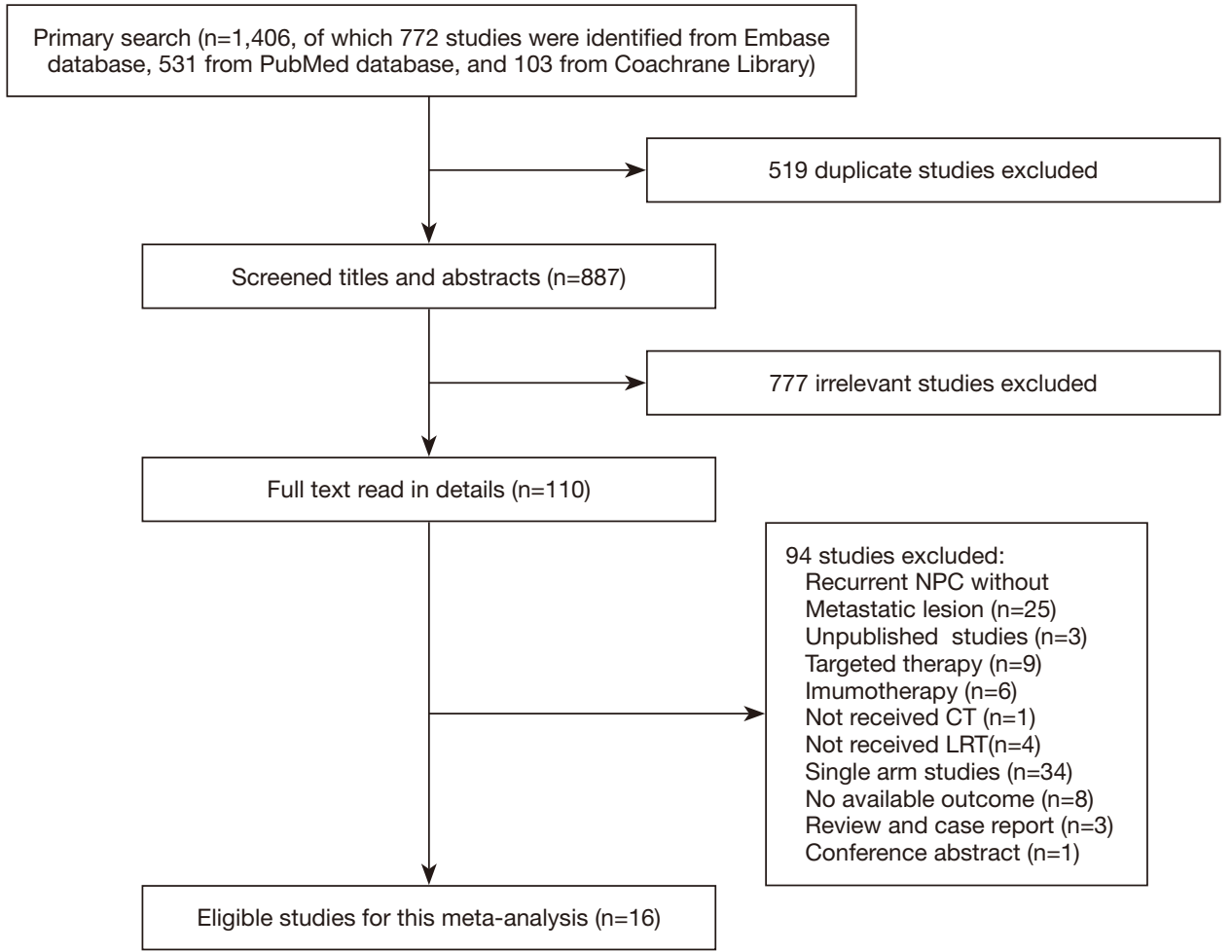

Figure 1 Flow diagram of selection of included and excluded studies.

weren't reported (the item scored 0), which caused followup bias. Besides, 12 studies collected and included only data for OS without PFS, and so the item 'endpoints appropriate to the aim of the study' was scored 1 , which would result in reporting bias. And other items that scored 0 or 1 could cause other aspects of bias. Finally, 4 studies were assessed as high-quality with scores ranging from 16 to 18 $(25,27,33,34)$, while the remaining studies were assessed as medium-quality with scores ranging from 13 to 15 .

\section{Meta-analysis of the efficacy for $L R T$}

In all included studies, 15 reported the specific OS or the rate of OS. But 1 study was RCT, while the other 14 studies were retrospective studies, which were enrolled the pooled meta-analysis. The pooled HR of OS indicated that combining LRT with CT could provide a survival benefit compared with $\mathrm{CT}$ alone, as presented in the Figure $2 A$ (HR, 0.49; 95\% CI, 0.41-0.58, $\mathrm{P}<0.0001$ ). However, this was a comparatively highly heterogeneous result $\left(\mathrm{P}=0.01, \mathrm{I}^{2}=55 \%\right)$. To decrease heterogeneity, individual studies were removed stepwise and as a result, heterogeneity was eliminated when the study of Sun 2019 (30) was omitted from the analysis. Finally, the pooled HR of OS was more statistically significant at 0.45 (95\% CI: 0.40$0.52, \mathrm{P}<0.00001$ ) (Figure $2 B$ ). And, there was no statistical difference between the pooled HR of OS and the OS of RCT of You R (0.45 vs. 0.42, $\mathrm{P}=0.85)$.

Furthermore, the pooled analysis of HR for PFS also demonstrated the benefit of the combine treatment. As displayed in Figure 3, the pooled HR for PFS was 0.37 (95\% CI: $0.29-0.49, \mathrm{P}<0.00001)$, with the little heterogeneity $\left(\mathrm{P}=0.27, \mathrm{I}^{2}=23 \%\right)$. Regarding indicators of short-term efficacy and local control, the pooled RR of ORR and DCR was 0.60 (95\% CI: 0.46-0.79, $\mathrm{P}=0.0002)$ and 0.77 (95\% CI: $0.71-0.85, \mathrm{P}<0.00001$ ), respectively (Figure 3 ). Both were significantly homogenous ( $\mathrm{P}$ value of $\mathrm{Chi}^{2}=0.12$ and 0.42 , respectively).

\section{Subgroup analysis}

Subgroup analysis was only used on the pooled HR of OS, due to the lack of sufficient studies that were suitable and the presence of high heterogeneity. Subgroup analysis was conducted using from the following parameters: initial metastases, single metastatic organ, local treatment and 
Table 1 Baseline characteristics of included studies

\begin{tabular}{|c|c|c|c|c|c|c|}
\hline Study & Study design & $\begin{array}{l}\text { Inclusion } \\
\text { period }\end{array}$ & $\begin{array}{l}\text { Median follow-up } \\
\text { duration (months) }\end{array}$ & $\begin{array}{l}\text { Number of } \\
\text { patients }\end{array}$ & Therapeutic intervention & Outcome \\
\hline $\begin{array}{l}\text { You et al. } \\
\text { 2020; (14) }\end{array}$ & $\begin{array}{l}\text { Randomized } \\
\text { controlled trial }\end{array}$ & 2014-2018 & $26.7(17.2-33.5)$ & 126 & $\begin{array}{l}\mathrm{CT}(\mathrm{PF}) \text { vs. CT + LRT (70 Gy): } \\
63 \text { vs. } 63\end{array}$ & $\begin{array}{l}\text { 2-year OS of CT and CT + } \\
\text { LRT: } 54.5 \% \text { and } 76.4 \% \text {; HR } \\
\text { (OS): } 0.42 \text { ( } 95 \% \mathrm{Cl}, 0.23- \\
\text { 0.77). } 2 \text {-year PFS of CT and } \\
\text { CT + LRT: } 1.6 \% \text { and } 16.9 \% \text {; } \\
\text { HR (PFS): } 0.36 \text { (95\% Cl, } \\
0.23-0.57)\end{array}$ \\
\hline $\begin{array}{l}\text { Cao et al. } \\
2011 ;(20)\end{array}$ & $\begin{array}{l}\text { Retrospective } \\
\text { cohort }\end{array}$ & 1998-2000 & NR & 116 & $\begin{array}{l}\text { CT (PF) vs. CT + LRT } \\
\text { (66-70 Gy): } 59 \text { vs. } 57\end{array}$ & $\begin{array}{l}\mathrm{HR}(\mathrm{OS}): 0.224 \\
(95 \% \mathrm{Cl}, 0.082-0.723)\end{array}$ \\
\hline $\begin{array}{l}\text { Chen et al. } \\
\text { 2013; (21) }\end{array}$ & $\begin{array}{l}\text { Retrospective } \\
\text { cohort }\end{array}$ & 2001-2009 & $19.2(0.7-134.1)$ & 345 & $\begin{array}{l}\text { CT (platinum-based } \\
\text { combination regimen) vs. CT+ } \\
\text { LRT ( } 40-84 \text { Gy): } 169 \text { vs. } 176\end{array}$ & HR (OS): 0.4 (95\% Cl, 0.3-0.5) \\
\hline $\begin{array}{l}\text { Gu et al. } \\
2020 ;(23)\end{array}$ & $\begin{array}{l}\text { Retrospective } \\
\text { cohort }\end{array}$ & 2010-2018 & $20[1-194]$ & 92 & $\begin{array}{l}\text { CT (DP or TP) vs. CT + LRT } \\
\text { (66-72 Gy): } 25 \text { vs. } 67\end{array}$ & $\begin{array}{l}\text { HR (PFS): } 0.476 \\
(95 \% \mathrm{Cl}, 0.288-0.784)\end{array}$ \\
\hline $\begin{array}{l}\text { Huang et al. } \\
2020 ;(24)\end{array}$ & $\begin{array}{l}\text { Retrospective } \\
\text { cohort }\end{array}$ & 2007-2018 & NR & 786 & $\begin{array}{l}\text { CT (GP, PF, TP or TPF) vs. CT + } \\
\text { LRT (unknown does): } \\
320 \text { vs. } 466\end{array}$ & $\begin{array}{l}\mathrm{HR}(\mathrm{OS}): 0.4 \text { (95\% Cl} \\
0.312-0.513) ; \mathrm{HR} \text { (PFS): } 0.372 \\
\text { (95\% Cl, 0.299-0.461) }\end{array}$ \\
\hline $\begin{array}{l}\text { Lin et al. } \\
\text { 2013; (25) }\end{array}$ & $\begin{array}{l}\text { Retrospective } \\
\text { cohort }\end{array}$ & 2003-2010 & $65.5[27-133]$ & 212 & $\begin{array}{l}\text { CT (GP, PF, TP, BPF or TPF) vs. } \\
\text { CT + LRT ( } 68-72 \text { Gy): } \\
105 \text { vs. } 107 .\end{array}$ & $\begin{array}{l}\text { Median OS of CT and CT + } \\
\text { LRT: } 16 \text { and } 36 \text { months; me- } \\
\text { dian PFS of CT and CT + LRT: } \\
7 \text { and } 28 \text { months; HR (OS): } \\
0.341(95 \% \mathrm{Cl}, 0.237-0.489)\end{array}$ \\
\hline $\begin{array}{l}\text { Pan et al. } \\
\text { 2018; (28) }\end{array}$ & Case-control & 2010-2015 & NR & 90 & $\begin{array}{l}\text { CT (PP) vs. CT + LRT (66 Gy): } \\
45 \text { vs. } 45\end{array}$ & $\begin{array}{l}\text { ORR and DCR of CT: } 33.3 \% \\
\text { and } 66.7 \% \text {; ORR and DCR of } \\
\text { CT + LRT: } 77.8 \% \text { and } 88.9 \% \text {; } \\
\text { 2-year OS of CT and CR + } \\
\text { LRT: } 64.4 \% \text { and } 86.7 \%\end{array}$ \\
\hline $\begin{array}{l}\text { Sun et al. } \\
2019 ;(29)\end{array}$ & $\begin{array}{l}\text { Retrospective } \\
\text { cohort }\end{array}$ & $2006-2010$ & $33.9[3-126]$ & 226 & $\begin{array}{l}\text { CT (TP, PF, TPF) vs. CT + LRT } \\
\text { (70 Gy): } 60 \text { vs. } 157\end{array}$ & $\begin{array}{l}\text { HR (OS): } 0.48 \\
(95 \% \mathrm{Cl}, 0.31-0.75)\end{array}$ \\
\hline $\begin{array}{l}\text { Sun et al. } \\
2019 ;(30)\end{array}$ & $\begin{array}{l}\text { Retrospective } \\
\text { cohort }\end{array}$ & 2007-2016 & $26.3[2-126]$ & 502 & $\begin{array}{l}\text { CT (TP, PF, GP, or TPF) vs. CT + } \\
\text { LRT (68-70 Gy): } 187 \text { vs. } 315\end{array}$ & $\begin{array}{l}\mathrm{HR}(\mathrm{OS}): 0.76 \\
(95 \% \mathrm{Cl}, 0.59-0.98)\end{array}$ \\
\hline
\end{tabular}

Table 1 (continued) 
Table 1 (continued)

\begin{tabular}{|c|c|c|c|c|c|c|}
\hline Study & Study design & $\begin{array}{l}\text { Inclusion } \\
\text { period }\end{array}$ & $\begin{array}{l}\text { Median follow-up } \\
\text { duration (months) }\end{array}$ & $\begin{array}{l}\text { Number of } \\
\text { patients }\end{array}$ & Therapeutic intervention & Outcome \\
\hline $\begin{array}{l}\text { Tian et al. } \\
\text { 2016; (31) }\end{array}$ & $\begin{array}{l}\text { Retrospective } \\
\text { cohort }\end{array}$ & $2001-2010$ & NR & 263 & $\begin{array}{l}\text { CT (TP, PF, or TPF) vs. CT + } \\
\text { LRT (44-78 Gy): } 103 \text { vs. } 160\end{array}$ & $\begin{array}{l}\mathrm{HR}(\mathrm{OS}): 0.63 \\
(95 \% \mathrm{Cl}, 0.44-0.91)\end{array}$ \\
\hline $\begin{array}{l}\text { Wang et al. } \\
\text { 2009; (32) }\end{array}$ & $\begin{array}{l}\text { Retrospective } \\
\text { cohort }\end{array}$ & 1997-2003 & $<36$ & 167 & $\begin{array}{l}\mathrm{CT} \text { (platinum-based combination } \\
\text { regimen) vs. CT + LRT (55- } \\
75 \text { Gy): } 82 \text { vs. } 85\end{array}$ & $\begin{array}{l}\text { 3-year OS of CT and CR + } \\
\text { LRT: } 14 \% \text { and } 25 \%\end{array}$ \\
\hline $\begin{array}{l}\text { Zheng et al. } \\
\text { 2016; (34) }\end{array}$ & $\begin{array}{l}\text { Retrospective } \\
\text { cohort }\end{array}$ & 2001-2010 & 36 [3-183] & 133 & $\begin{array}{l}\mathrm{CT} \text { (TP, PF, GP, or other } \\
\text { platinum-based combination } \\
\text { regimen) vs. CT + LRT (30- } \\
70 \text { Gy): } 55 \text { vs. } 78\end{array}$ & $\begin{array}{l}\text { 2-year OS of CT and CR + } \\
\text { LRT: } 32.7 \% \text { and } 55.7 \%\end{array}$ \\
\hline
\end{tabular}

PFS, progression free survival; OS, overall survival; ORR, objective response rate; DCR, disease control rate; HR, hazard ratio; CI, confidence interval; NR, not reported; PF, cisplatin and 5-flfluorouracil; DP, docetaxel and cisplatin; TP, paclitaxel and cisplatin; TPF, paclitaxel, cisplatin and 5-fluorouracil; GP, gemcitabine and cisplatin; BPF, bleomycin, cisplatin and 5-flfluorouracil; PP, pemetrexed and cisplatin.

recruitment date. All M-NPC patients in 8 studies had been recently diagnosed, with only a proportion of the patients in 5 other studies recently diagnosed. Subgroup A1 (all patients were initial metastases) had the higher heterogeneity $\left(\mathrm{I}^{2}=66 \%\right)$, while subgroup A2 (partial patients were initial metastases) had no heterogeneity $\left(\mathrm{I}^{2}=0 \%\right.$ ) (Figure $\mathrm{S} 1$ ). The pooled HR of subgroup A1 was 0.49 (95\% CI: $0.39-0.62$ ), and 0.42 (95\% CI: 0.34-0.51) for subgroup A2. The value of P-interaction was 0.28 in a test of subgroup differences (Table 2). For patients with a single metastatic organ, subgroup B1 (all patients had single metastatic organ) displayed significant homogeneity $\left(\mathrm{I}^{2}=0 \%\right.$ ), while subgroup B2 (not all patients had single metastatic organ) exhibited the higher heterogeneity $\left(\mathrm{I}^{2}=70 \%\right)$ (Figure $\mathrm{S} 2$ ). The pooled HRs of subgroups B1 and B2 were 0.43 (95\% CI: 0.32-0.57) and 0.49 (95\% CI: 0.39 0.62) respectively, with the $\mathrm{P}$-interaction of 0.43 (Table 2). In addition, local treatment of metastatic lesions may be an influencing factor for survival. A proportion of patients in 9 studies received local treatment (subgroup C1), of which subgroup analysis indicated an absence of heterogeneity $\left(\mathrm{I}^{2}=0 \%\right)$, with pooled HR of 0.45 (95\% CI: $0.39-0.51$ ) (Figure S3, Table 2). Patients of the other 5 studies didn't receive local treatment (subgroup C2). Subgroup analysis demonstrated high heterogeneity $\left(\mathrm{I}^{2}=78 \%\right)$ with a pooled
HR of 0.51 (95\% CI: 0.34-0.75) (Figure S3, Table 2). The value of $\mathrm{P}$-interaction in this subgroup analysis was 0.55 . In addition, because the presentation of patients at different time points could also affect the final outcome, subgroup analysis was conducted where a recruitment date of 2010 was selected as the point of demarcation. The $\mathrm{I}^{2}$ statistics of subgroup D1 (recruitment period earlier than 2010) and subgroup D2 (recruitment period later than 2010) were $0 \%$ and $85 \%$, respectively (Figure S4). From subgroup analysis, the pooled HRs of D1 and D2 were calculated to be 0.44 (95\% CI: $0.39-0.51$ ) and 0.60 (95\% CI: 0.37-0.96), respectively. The value of $\mathrm{P}$-interaction between these two subgroups was 0.24 .

\section{Sensitivity analysis and publication bias}

As mentioned above, sensitivity analysis was done by removing literature stepwise and comparing the change of heterogeneity. $\mathrm{P}$ value of the $\mathrm{Chi}^{2}$ test and $\mathrm{I}^{2}$ statistical value had no significant change in sensitivity analysis of PFS, ORR and DCR. While in sensitivity analysis of OS, heterogeneity was eliminated after removing the study of Sun 2019 (30).

There were an insufficient number of studies, when considering the pooled analysis for ORR and DCR, and HR for PFS, to meet the requirements for analysis 


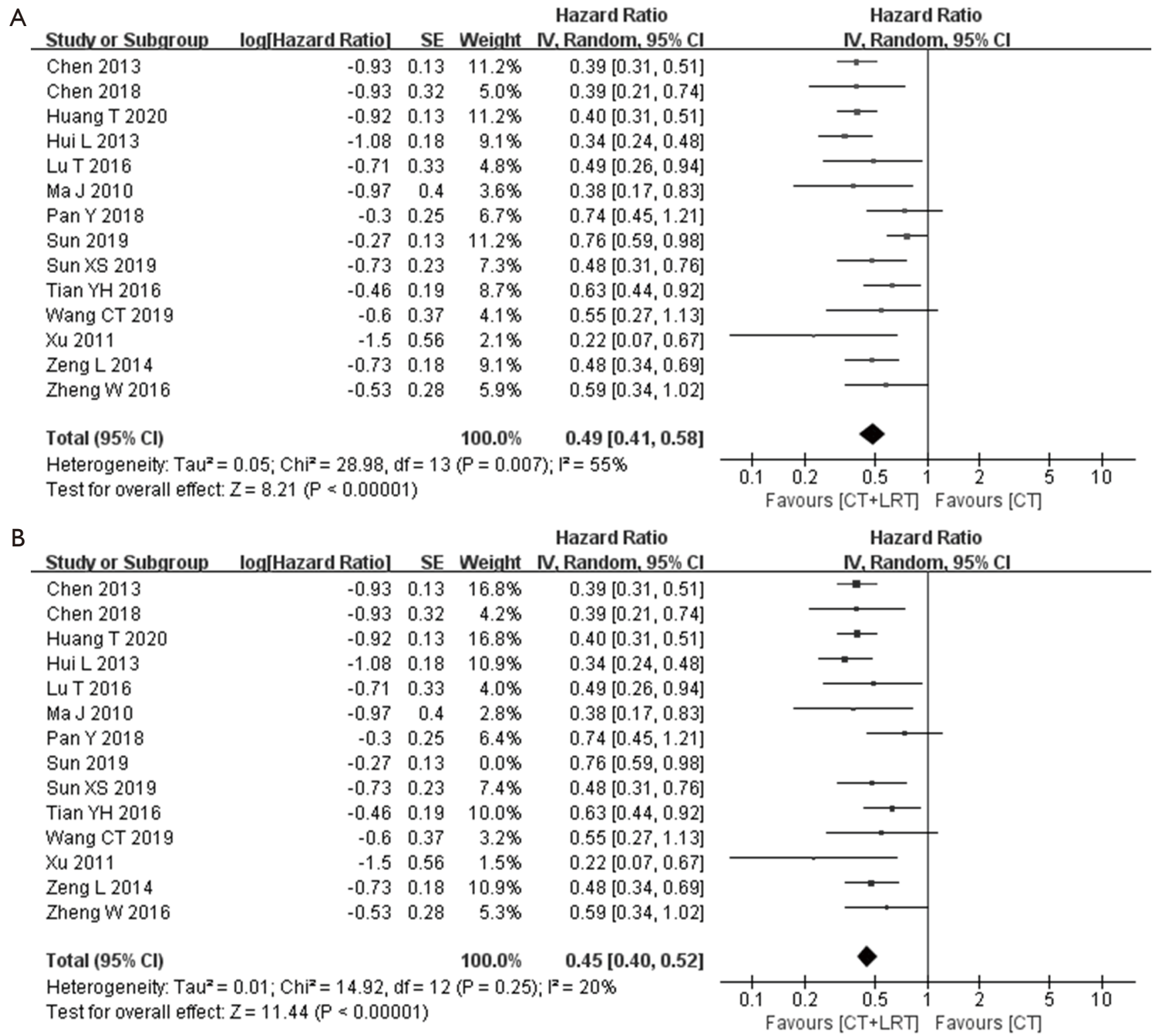

Figure 2 Forest plots of HR for OS between CT + LRT and CT alone. (A) Unadjusted HR for OS, included 14 studies; (B) adjusted HR for OS, removed the study of Sun 2019. HR, hazard ratio; OS, overall survival; CT, chemotherapy; LRT, locoregional radiotherapy.

of publication bias and so it was analyzed only in terms of pooled HR of OS. Funnel plots of HR for OS were presented in Figure 4, in which the left and right sides were symmetrical. The P value of Egger's test for bias was 0.709 , indicating an absence of publication bias.

\section{Discussion}

In the present meta-analysis, the pooled HR of OS and
PFS, and the pooled RR of ORR and DCR were calculated. All values of indicators of efficacy indicators demonstrated that LRT combined with CT was superior to CT alone in M-NPC patients, a difference that was statistically significant without being affected by heterogeneity. From the perspective of evaluation of efficacy, it is possibly not surprising that combining CT with LRT would improve the ORR and DCR in M-NPC patients. However, to better understand the long-term efficacy of LRT, more in-depth 


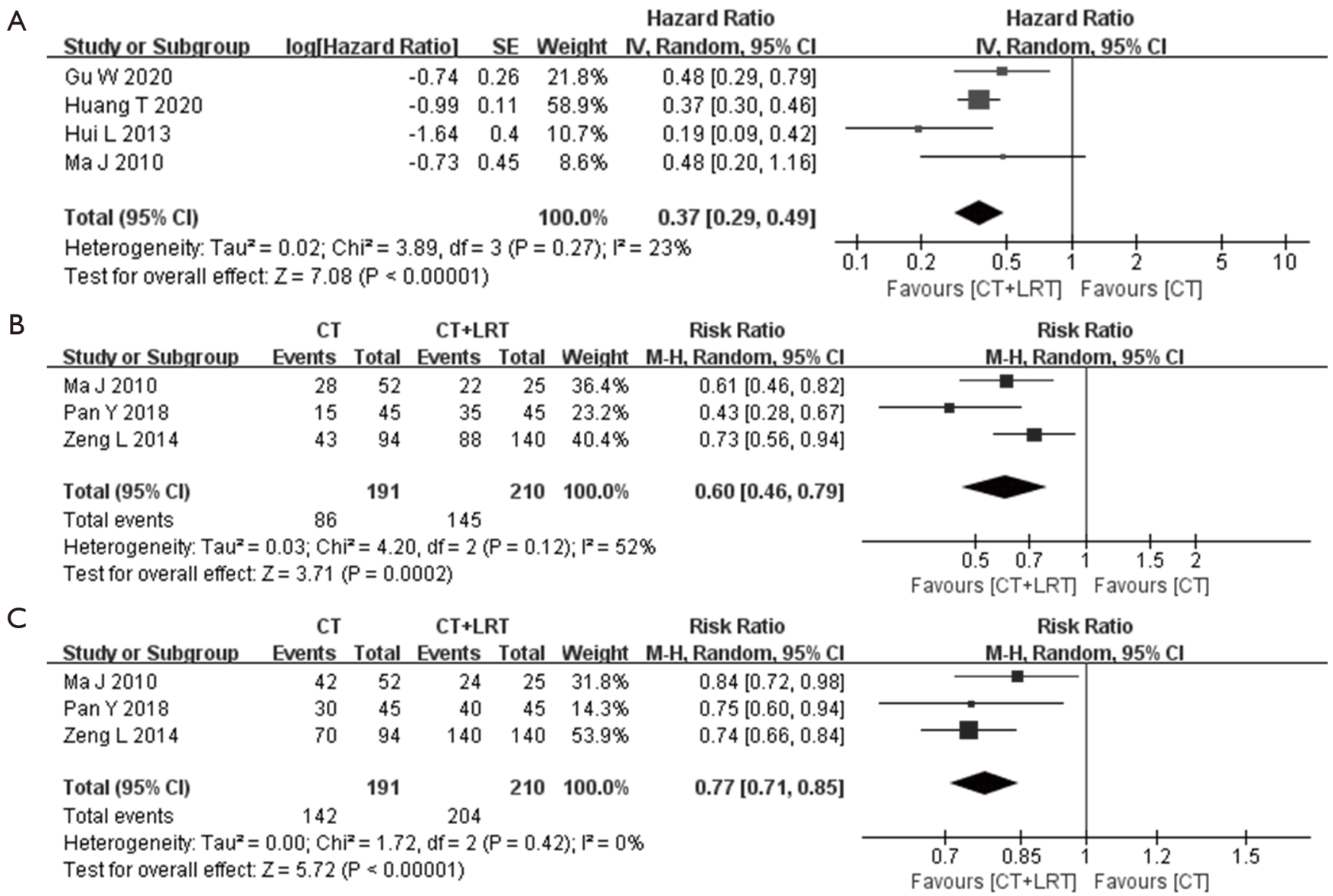

Figure 3 Forest plots of HR for PFS, RR for ORR and DCR between CT + LRT and CT alone. (A) HR for PFS; (B) RR for ORR; (C) RR for DCR. HR, hazard ratio; PFS, progression-free survival; RR, risk ratio; ORR, objective response rate; DCR, disease control rate; CT, chemotherapy; LRT, locoregional radiotherapy.

analysis was required.

In the initial pooled analysis of HR for OS, pooled HR was 0.48 (95\% CI: 0.41-0.57) with the high heterogeneity $\left(\mathrm{I}^{2}=52 \%\right)$. By removing the study of Sun 2019, the adjusted HR was 0.45 (95\% CI: $0.40-0.51$ ), with no heterogeneity $\left(I^{2}=13 \%\right)$. The unadjusted HR was higher than the adjusted HR, while the HR (0.76, 95\% CI: 0.59-0.98) of the study of Sun 2019 was the highest of the 15 studies included in the analysis of HR for OS, suggesting that LRT plus CT provided a reduced survival benefit in Sun's study compared with other studies. In the analysis of the 4 subgroups, a decrease in heterogeneity in one subgroup was accompanied by increased heterogeneity in other subgroups. Subgroup analysis did not identify the source of heterogeneity, because decreased heterogeneity of each subgroup was not observed. Thus, the study of Sun 2019 was uniquely the source of heterogeneity (30). However, the authors did not provide relevant information about the specific distribution of patients who received LRT with CT and those that received $\mathrm{CT}$ alone. Otherwise, we did not identify any special differences in the characteristics of patients or therapeutic intervention compared with the other studies. In Sun's study, 502 patients with de novo M-NPC were recruited, of whom 315 received LRT and 128 had multiple organ metastases. Possibly the majority of patients with multiple organ metastases received LRT, which weakened the apparent effectiveness of LRT. This assumption requires confirmation in a future clinical study. In addition, Sun et al. divided the M-NPC patients into two subgroups: a low-risk group with undetectable levels of Epstein-Barr virus (EBV) DNA and satisfactory tumor response (CR/ PR) following CT, and a high-risk subgroup with detectable 
Table 2 The characteristics of subgroup analysis and test for subgroup differences about pooled HR of OS

\begin{tabular}{|c|c|c|c|c|c|}
\hline Group & No. of studies & $\mathrm{HR}(95 \% \mathrm{Cl})$ & P-heterogeneity & $\mathrm{I}^{2}(\%)$ & P-interaction \\
\hline Initial metastases & & & & & 0.28 \\
\hline All patients were initial metastases & 8 & $0.49(0.39,0.62)$ & 0.005 & 66 & \\
\hline Partial patients were initial metastases & 5 & $0.42(0.34,0.51)$ & 0.52 & 0 & \\
\hline All patients had single metastatic organ & 5 & $0.43(0.32,0.57)$ & 0.74 & 0 & \\
\hline Not all patients had single metastatic organ & 8 & $0.49(0.39,0.62)$ & 0.001 & 70 & \\
\hline Local treatment & & & & & 0.55 \\
\hline Partial patients received local treatment & 9 & $0.45(0.39,0.51)$ & 0.56 & 0 & \\
\hline Recruitment period was earlier than 2010 & 11 & $0.44(0.39,0.51)$ & 0.44 & 0 & \\
\hline Recruitment period was later than 2010 & 3 & $0.60(0.37,0.96)$ & 0.001 & 85 & \\
\hline
\end{tabular}

$\mathrm{HR}$, hazard ratio; OS, overall survival.

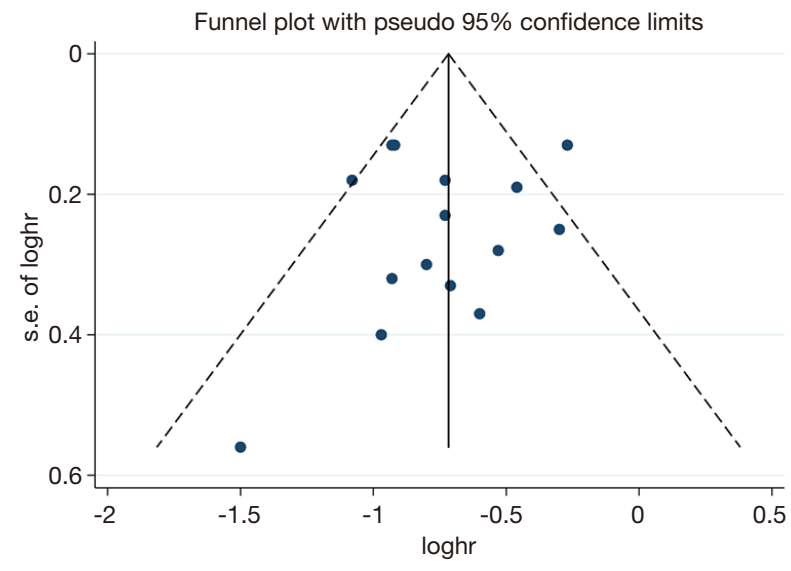

Figure 4 Funnel plot with $95 \%$ confidence limits of HR for OS between CT + LRT and CT alone. P value was calculated by Egger's test. HR, hazard ratio; OS, overall survival; CT, chemotherapy; LRT, locoregional radiotherapy.

EBV DNA and/or unsatisfactory tumor response (SD/PD) post-CT. Ultimately, LRT displayed a better OS in the low-risk subgroup (HR 0.35, 95\% CI: 0.21-0.58), while the HR for OS was 0.76 across the whole cohort. It is probable that high plasma levels of EBV DNA or poor sensitivity to CT would weaken the survival benefits of LRT in M-NPC patients. Conversely, to achieve better short-term efficacy, it would be reasonable to expect that patients who had unsatisfactory tumor response to CT would be more likely to receive LRT. The proportion of patients receiving radiotherapy was high in the high-risk group, while the proportion was low in the low-risk group, causing the HR for OS across the whole cohort to be close to 1. In the RCT of You et al., only patients who achieved CR or PR after 3 cycles of neoadjuvant chemotherapy could be included, maybe they wanted to get the support of Ethics Committee. So, it was still unknown if the M-NPC patients who had unsatisfactory tumor response (SD/PD) after unsatisfactory tumor response (SD/PD) post-CT could benefit from LRT. Also, to some extents, this unclear fact supported the surmise mentioned above.

Of the 4 subgroup analyses of pooled HR for OS, no significant difference was found in either subgroup. As to the first three subgroup analyses, negative conclusions had no clinical value. Therefore it remains unclear whether initial metastases, or single metastatic organ, or local treatment is able to enhance the efficacy of LRT. In subgroup analysis of recruitment period, the pooled HR of the two subgroups was not significantly different. This suggests that LRT achieved a similar efficacy in patients after different periods of time, and also suggests that different radiotherapy techniques did not affect the efficacy of LRT. However, the recorded baseline patient 
characteristics were not consistent across the studies included in this review, such as the number of metastatic organs and lesions, the therapeutic intervention, dose of radiotherapy, level of EBV DNA, etc. For this reason, it is not possible to evaluate with certainty which factor influenced the efficacy of LRT. In a number of studies included in the present meta-analysis, researchers identified factors that potentially enhanced or weakened the efficacy of LRT. Cao et al. concluded that the disease-free interval, local recurrence, subsequent metastasis, and age influenced the efficacy of LRT (20). In addition, Tian et al. screened 7 factors that indicate poor prognosis related to the efficacy of LRT, such as the Karnofsky performance score, multipleorgan metastases, number of metastatic lesions, etc. (35). These risk factors could be thought as covariates comparing to the independent variable 'LRT', but the included studies adjusted different covariates. Some retrospective studies considered these covariates could weaken the efficacy of CT + LRT, and this meta-analysis failed to keep the covariates of included studies consistent. So, the real HR of OS for CT plus LRT compared with CT alone may be larger than the one calculated by this meta-analysis. However, due to different experimental designs, a variety of influencing factors could be identified, liable to complicate the risk stratification and magnify a number of already unrelated factors. Therefore, prospective controlled trials are warranted to clarify definitive factors that enhance or weaken the efficacy of LRT.

As a form of local treatment, radiotherapy can lengthen the survival of patients with metastatic diseases, which confuses the overall data. Although radiotherapy is thought to be highly correlated with spatial accuracy, it can stimulate various systemic phenomena and occasionally contributes to regression and rejection of non-irradiated, distant tumor lesions (36,37). Historically, radiotherapy has been shown to cause immunosuppressive effects and immunological tolerance due to lymphocytopenia and suppression of T-cell activation (38). It is possible that local therapy could systemically activate the immune system and counteract the effect of irradiation of the tumor in addition to distant, outof-field metastases (36). Besides, some researchers thought the shrinkage of primary tumor lesion via local radiotherapy cause lower tumor burden, and could delay the seeding of subsequent tumor clones at distant sites $(39,40)$. However, the potential mechanisms still need future work to testify and understand.

The present meta-analysis is first to compare LRT plus CT with CT alone in M-NPC patients. It is worth mentioning the limitations of the study. Firstly, the majority of the studies identified for inclusion were retrospective and observational, and the characteristics of the recruited patients and therapeutic interventions were complex and miscellaneous, leading to failure of subgroup analysis and undefinable bias. Secondly, a number of statistical values were calculated mathematically, also a cause of bias. Thirdly, the recruited patients in a number of different studies lived in the same geographical area, raising the possibility that the same patients were included in different studies. Fourthly, a number of excluded studies recruited recurrent and metastatic NPC patients not recommended for LRT. However, the data of these patients could not easily be excluded from those studies, resulting in potentially missing studies and data in the calculation of pooled HR and ORR. Fifthly, when calculating the pooled HR for PFS, and pooled RR for ORR and DCR, only 3-4 studies were included. The small sample size may lead to conclusions that cannot be applied universally. Besides, non-English databases were not searched, so the language bias may cause the conclusion wasn't applicable to nonEnglish speaking areas. Finally, the present analysis failed to analyze and compare the incidence of adverse events in the two groups of patients.

\section{Conclusions}

In summary, the present meta-analysis demonstrated that CT + LRT is superior to CT alone and provides higher values of OS, PFS, ORR, and DCR compared with CT alone. Therefore, CT plus LRT should be a better choice for M-NPC patients. This conclusion should also be confirmed in prospective controlled studies that compare CT + LRT with CT alone.

\section{Acknowledgments}

Funding: None.

\section{Footnote}

Reporting Checklist: The authors have completed the PRISMA reporting checklist. Available at http://dx.doi. org/10.21037/apm-20-1561

Conflicts of Interest: Both authors have completed the ICMJE uniform disclosure form (available at http://dx.doi. org/10.21037/apm-20-1561). The authors have no conflicts 
of interest to declare.

Ethical Statement: The authors are accountable for all aspects of the work in ensuring that questions related to the accuracy or integrity of any part of the work are appropriately investigated and resolved.

Open Access Statement: This is an Open Access article distributed in accordance with the Creative Commons Attribution-NonCommercial-NoDerivs 4.0 International License (CC BY-NC-ND 4.0), which permits the noncommercial replication and distribution of the article with the strict proviso that no changes or edits are made and the original work is properly cited (including links to both the formal publication through the relevant DOI and the license). See: https://creativecommons.org/licenses/by-nc-nd/4.0/.

\section{References}

1. Liao W, Tian M, Chen N. Characteristic and novel therapeutic strategies of nasopharyngeal carcinoma with synchronous metastasis. Cancer Manag Res 2019;11:8431-42.

2. Kamran SC, Riaz N, Lee N. Nasopharyngeal carcinoma. Surg Oncol Clin N Am 2015;24:547-61.

3. Chua MLK, Wee JTS, Hui EP, et al. Nasopharyngeal carcinoma. Lancet 2016;387:1012-24.

4. Torre LA, Bray F, Siegel RL, et al. Global cancer statistics, 2012. CA Cancer J Clin 2015;65:87-108.

5. Lee AW, Ma BB, Ng WT, et al. Management of Nasopharyngeal Carcinoma: Current Practice and Future Perspective. J Clin Oncol 2015;33:3356-64.

6. Lee AWM, Ng WT, Chan LK, et al. The strength/ weakness of the AJCC/UICC staging system (7th edition) for nasopharyngeal cancer and suggestions for future improvement. Oral Oncol 2012;48:1007-13.

7. Chen YP, Chan ATC, Le QT, et al. Nasopharyngeal carcinoma. Lancet 2019;394:64-80.

8. Tan WL, Tan EH, Lim DW, et al. Advances in systemic treatment for nasopharyngeal carcinoma. Chin Clin Oncol 2016;5:21-3.

9. Jain A, Chia WK and Toh HC. Immunotherapy for nasopharyngeal cancer-a review. Chin Clin Oncol 2016;5: 22-24.

10. Lee V, Kwong D, Leung TW, et al. Palliative systemic therapy for recurrent or metastatic nasopharyngeal carcinoma - How far have we achieved? Crit Rev Oncol Hematol 2017;114:13-23.
11. Colevas AD, Yom SS, Pfister DG, et al. NCCN Guidelines Insights: Head and Neck Cancers, Version 1.2018. J Natl Compr Canc Netw 2018;16:479-90.

12. Hu J, Kong L, Gao J, et al. Use of Radiation Therapy in Metastatic Nasopharyngeal Cancer Improves Survival: A SEER Analysis. Sci Rep 2017;7:721-7.

13. Rusthoven CG, Lanning RM, Jones BL, et al. Metastatic nasopharyngeal carcinoma: Patterns of care and survival for patients receiving chemotherapy with and without local radiotherapy. Radiother Oncol 2017;124:139-46.

14. You R, Liu YP, Huang PY, et al. Efficacy and Safety of Locoregional Radiotherapy With Chemotherapy vs Chemotherapy Alone in De Novo Metastatic Nasopharyngeal Carcinoma: A Multicenter Phase 3 Randomized Clinical Trial. JAMA Oncol 2020;6:1345-52.

15. Zeng X, Zhang Y, Kwong JS, et al. The methodological quality assessment tools for preclinical and clinical studies, systematic review and meta-analysis, and clinical practice guideline: a systematic review. J Evid Based Med 2015;8:2-10.

16. Slim K, Nini E, Forestier D, et al. Methodological index for non-randomized studies (minors): development and validation of a new instrument. ANZ J Surg 2003;73:712-6.

17. Higgins JP, Altman DG, Gotzsche PC, et al. The Cochrane Collaboration's tool for assessing risk of bias in randomised trials. BMJ 2011;343:d5928-5936.

18. Tierney JF, Stewart LA, Ghersi D, et al. Practical methods for incorporating summary time-to-event data into metaanalysis. Trials 2007;8:16-31.

19. Higgins JP, Thompson SG, Deeks JJ, et al. Measuring inconsistency in meta-analyses. BMJ 2003;327:557-60.

20. Cao X, Han Y, He L, et al. Risk subset of the survival for nasopharyngeal carcinoma patients with bone metastases: who will benefit from combined treatment? Oral Oncol 2011;47:747-52.

21. Chen MY, Jiang R, Guo L, et al. Locoregional radiotherapy in patients with distant metastases of nasopharyngeal carcinoma at diagnosis. Chin J Cancer 2013;32:604-13.

22. Chen $\mathrm{C}, \mathrm{Wu}$ JB, Jiang H, et al. A Prognostic Score for Nasopharyngeal Carcinoma with Bone Metastasis: Development and Validation from Multicenter. J Cancer 2018;9:797-806.

23. Gu W, Yu F, Mao Q, et al. Prognostic analysis of peripheral blood inflammatory markers in 99 nasopharyngeal carcinoma patients with recurrence and metastasis. Precision Radiation Oncology 2020;4:18-24.

24. Huang T, Su N, Zhang X, et al. Systemic chemotherapy 
and sequential locoregional radiotherapy in initially metastatic nasopharyngeal carcinoma: Retrospective analysis with 821 cases. Head Neck 2020;42:1970-80.

25. Lin H, Lin HX, Cai XY, et al. Chemotherapy plus radiotherapy makes curability a possibility in nasopharyngeal carcinoma patients with distant metastasis at diagnosis. Head Neck Oncol 2013;5:1.

26. Lu T, Guo Q, Cui X, et al. Prognostic Evaluation of Nasopharyngeal Carcinoma with Bone-Only Metastasis after Therapy. Yonsei Med J 2016;57:840-5.

27. Ma J, Wen ZS, Lin P, et al. The results and prognosis of different treatment modalities for solitary metastatic lung tumor from nasopharyngeal carcinoma: a retrospective study of 105 cases. Chin J Cancer 2010;29:787-95.

28. Pan Y, Huang J, Huang J, et al. Efficacy analysis of radical intensity-modulated radiotherapy combined with concurrent chemotherapy for treatment of metastatic nasopharyngeal carcinoma. Cancer Research and Clinic 2018;30:400-3.

29. Sun XS, Liang YJ, Liu SL, et al. Subdivision of Nasopharyngeal Carcinoma Patients with Bone-Only Metastasis at Diagnosis for Prediction of Survival and Treatment Guidance. Cancer Res Treat 2019;51:1259-68.

30. Sun XS, Liu LT, Liu SL, et al. Identifying optimal candidates for local treatment of the primary tumor among patients with de novo metastatic nasopharyngeal carcinoma: a retrospective cohort study based on EpsteinBarr virus DNA level and tumor response to palliative chemotherapy. BMC Cancer 2019;19:92-101.

31. Tian YH, Zou WH, Xiao WW, et al. Oligometastases in AJCC stage IVc nasopharyngeal carcinoma: A subset with better overall survival. Head Neck 2016;38:1152-7.

32. Wang CT, Cao KJ, Xie GF, et al. Prognosis analysis of nasopharyngeal carcinoma patients with distant metastasis at preliminary diagnosis. Chinese Journal of Cancer Prevention and Treatment 2009;16:439-42.

33. Zeng L, Tian YM, Huang Y, et al. Retrospective analysis of 234 nasopharyngeal carcinoma patients with distant metastasis at initial diagnosis: therapeutic approaches and prognostic factors. PLoS One 2014;9:e108070.

34. Zheng W, Zong J, Huang C, et al. Multimodality Treatment May Improve the Survival Rate of Patients with Metastatic Nasopharyngeal Carcinoma with Good Performance Status. PLoS One 2016;11:e0146771.

35. Tian YM, Huang WZ, Lan YH, et al. Prognostic model and optimal treatment for patients with stage IVc nasopharyngeal carcinoma at diagnosis. Sci Rep 2019;9:19272.

36. Brix N, Tiefenthaller A, Anders H, et al. Abscopal, immunological effects of radiotherapy: Narrowing the gap between clinical and preclinical experiences. Immunol Rev 2017;280:249-79.

37. Reynders K, Illidge T, Siva S, et al. The abscopal effect of local radiotherapy: using immunotherapy to make a rare event clinically relevant. Cancer Treat Rev 2015;41:503-10.

38. Cao MD, Chen ZD and Xing Y. Gamma irradiation of human dendritic cells influences proliferation and cytokine profile of $\mathrm{T}$ cells in autologous mixed lymphocyte reaction. Cell Biol Int 2004;28:223-8.

39. Kaplan RN, Psaila B, Lyden D. Bone marrow cells in the 'pre-metastatic niche': within bone and beyond, Cancer Metastasis Rev 2006;25:521-9.

40. Hiratsuka S, Watanabe A, Aburatani H. Tumour-mediated upregulation of chemoattractants and recruitment of myeloid cells predetermines lung metastasis, Nat Cell Biol 2006;8:1369-75.
Cite this article as: Wang G, Shen L. The efficacy of locoregional radiotherapy plus chemotherapy $v$ s. chemotherapy alone in metastatic nasopharyngeal carcinoma: a meta-analysis. Ann Palliat Med 2021;10(3):2584-2595. doi: 10.21037/apm-20-1561 
Supplementary

Hazard Ratio

Hazard Ratio

Study or Subgroup log[Hazard Ratiol SE Weight IV. Random, 95\% C IV. Random, 95\% Cl

2.2.1 all patients were initial metastases

Huang T 2020

Hui L 2013

$\begin{array}{lll}-0.92 & 0.13 \quad 12.1 \%\end{array}$

$\begin{array}{lll}-1.08 & 0.18 & 9.8 \%\end{array}$

$0.40[0.31,0.51]$

Ma J 2010

$\begin{array}{lll}-0.97 & 0.4 & 3.8 \%\end{array}$

$0.34[0.24,0.48]$

Sun 2019

$\begin{array}{lll}-0.27 & 0.13 & 12.1 \%\end{array}$

$0.38[0.17,0.83]$

Sun XS 2019

$\begin{array}{lll}-0.73 & 0.23 & 7.8 \%\end{array}$

$0.76[0.59,0.98]$

Tian YH 2016

$\begin{array}{lll}-0.46 & 0.19 & 9.4 \%\end{array}$

Wang CT 2019

$\begin{array}{lll}-0.6 & 0.37 & 4.3 \%\end{array}$

$0.48[0.31,0.76]$

$0.63[0.44,0.92]$

$-0.73 \quad 0.18 \quad 9.8 \%$

$0.55[0.27,1.13]$

Zeng L 2014

Subtotal $(95 \% \mathrm{CI})$

$69.2 \%$

$0.48[0.34,0.69]$

$0.49[0.39,0.62]$

Heterogeneity: Tau $^{2}=0.07 ; \mathrm{Ch}^{2}=20.33, \mathrm{df}=7(\mathrm{P}=0.005) ; \mathrm{I}^{2}=66 \%$

Test for overall effect: $Z=5.93$ ( $P<0.00001$ )

2.2.2 partial patients were initial metastases

$\begin{array}{lrrrr}\text { Chen } 2013 & -0.93 & 0.13 & 12.1 \% & 0.39[0.31,0.51] \\ \text { Chen 2018 } & -0.93 & 0.32 & 5.2 \% & 0.39[0.21,0.74] \\ \text { Lu T 2016 } & -0.71 & 0.33 & 5.0 \% & 0.49[0.26,0.94] \\ \text { Xu 2011 } & -1.5 & 0.56 & 2.2 \% & 0.22[0.07,0.67] \\ \text { Zheng W 2016 } & -0.53 & 0.28 & 6.2 \% & 0.59[0.34,1.02] \\ \text { Subtotal (95\% Cl) } & & & 30.8 \% & \mathbf{0 . 4 2}[\mathbf{0 . 3 4}, \mathbf{0 . 5 1}]\end{array}$

Heterogeneity: $\operatorname{Tau}^{2}=0.00 ; \mathrm{Chi}^{2}=3.22, \mathrm{df}=4(P=0.52) ; \mathrm{I}^{2}=0 \%$

Test for overall effect: $Z=8.47$ ( $P<0.00001$ )

\subsubsection{Unknown}

Pan Y 2018

$-0.3 \quad 0.25$

Not estimable

Subtotal $(95 \% \mathrm{Cl})$

Not estimable

Heterogeneity: Not applicable

Test for overall effect: Not applicable

Total (95\% Cl)

$100.0 \%$

$0.47[0.40,0.56]$

Heterogeneity: $\mathrm{Tau}^{2}=0.05 ; \mathrm{Chi}^{2}=26.10, \mathrm{df}=12(\mathrm{P}=0.01) ; \mathrm{I}^{2}=54 \%$

Test for overall effect: $Z=8.41$ ( $P<0.00001$ )

Test for subaroun differences: $\mathrm{Chi}^{2}=1.17 . \mathrm{df}=1(\mathrm{P}=0.28) . \mathrm{I}^{2}=14.7 \%$

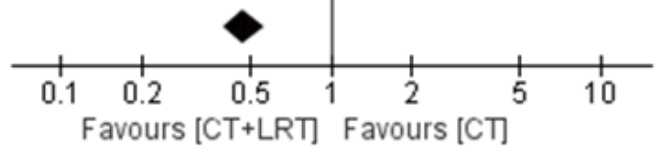

Figure S1 Forest plots of subgroup analysis according to initial metastases. 
Table S1 Result of quality assessment by using the methodological index for non-randomized studies (minors) for involved studies

\begin{tabular}{|c|c|c|c|c|c|c|c|c|c|c|c|c|c|}
\hline Study & $\begin{array}{l}\text { A clearly stated } \\
\text { aim }^{\mathrm{a}}\end{array}$ & $\begin{array}{l}\text { Inclusion of } \\
\text { consecutive } \\
\text { patients }\end{array}$ & $\begin{array}{c}\text { Prospective } \\
\text { collection of } \\
\text { data }^{c}\end{array}$ & $\begin{array}{c}\text { Endpoints } \\
\text { appropriate to } \\
\text { the aim of the } \\
\text { study }^{d}\end{array}$ & $\begin{array}{l}\text { Unbiased } \\
\text { assessment of } \\
\text { the study } \\
\text { endpoint }^{e}\end{array}$ & $\begin{array}{l}\text { Follow-up } \\
\text { period } \\
\text { appropriate to } \\
\text { the aim of the } \\
\text { study }\end{array}$ & $\begin{array}{l}\text { Loss to } \\
\text { follow up less } \\
\text { than } 5 \%{ }^{9}\end{array}$ & $\begin{array}{l}\text { Prospective } \\
\text { calculation of } \\
\text { the study size }\end{array}$ & $\begin{array}{l}\text { An adequate } \\
\text { control group }\end{array}$ & $\begin{array}{l}\text { Contemporary } \\
\text { groups }\end{array}$ & $\begin{array}{l}\text { Baseline } \\
\text { equivalence of } \\
\text { groups }\end{array}$ & $\begin{array}{l}\text { Adequate } \\
\text { statistical } \\
\text { analyses }\end{array}$ & Score \\
\hline $\begin{array}{l}\text { Cao et al. } \\
2011 ;(20)\end{array}$ & 1 & 2 & 0 & 1 & 1 & 0 & 2 & 0 & 2 & 2 & 1 & 2 & 14 \\
\hline $\begin{array}{l}\text { Chen et al. } \\
\text { 2013; (21) }\end{array}$ & 2 & 2 & 0 & 1 & 1 & 1 & 1 & 0 & 1 & 2 & 1 & 2 & 14 \\
\hline $\begin{array}{l}\text { Chen et al. } \\
\text { 2018; (22) }\end{array}$ & 1 & 2 & 0 & 1 & 1 & 0 & 2 & 0 & 1 & 2 & 1 & 2 & 13 \\
\hline $\begin{array}{l}\text { Gu et al. } \\
2020 \text { (23) }\end{array}$ & 1 & 2 & 0 & 1 & 1 & 1 & 2 & 0 & 2 & 2 & 1 & 2 & 15 \\
\hline $\begin{array}{l}\text { Huang et al. } \\
\text { 2020; (24) }\end{array}$ & 2 & 2 & 0 & 2 & 1 & 0 & 2 & 0 & 1 & 2 & 1 & 2 & 15 \\
\hline $\begin{array}{l}\text { Lin et al. } \\
\text { 2013; (25) }\end{array}$ & 2 & 2 & 0 & 2 & 1 & 2 & 2 & 0 & 2 & 2 & 1 & 2 & 18 \\
\hline $\begin{array}{l}\text { Lu et al. } \\
\text { 2016; (26) }\end{array}$ & 1 & 2 & 0 & 1 & 1 & 1 & 2 & 0 & 1 & 2 & 1 & 2 & 14 \\
\hline $\begin{array}{l}\text { Ma et al. } \\
\text { 2010; (27) }\end{array}$ & 2 & 2 & 0 & 2 & 1 & 2 & 2 & 0 & 1 & 2 & 1 & 2 & 17 \\
\hline $\begin{array}{l}\text { Pan et al. } \\
\text { 2018; (28) }\end{array}$ & 2 & 2 & 0 & 1 & 1 & 0 & 2 & 0 & 1 & 2 & 1 & 2 & 14 \\
\hline $\begin{array}{l}\text { Sun et al. } \\
\text { 2019; (29) }\end{array}$ & 1 & 2 & 0 & 1 & 1 & 1 & 2 & 0 & 1 & 2 & 1 & 2 & 14 \\
\hline $\begin{array}{l}\text { Sun et al. } \\
\text { 2019; (30) }\end{array}$ & 1 & 2 & 0 & 1 & 1 & 1 & 2 & 0 & 2 & 2 & 1 & 2 & 15 \\
\hline $\begin{array}{l}\text { Tian et al. } \\
\text { 2016; (31) }\end{array}$ & 1 & 2 & 0 & 1 & 1 & 0 & 2 & 0 & 1 & 2 & 1 & 2 & 13 \\
\hline $\begin{array}{l}\text { Wang et al. } \\
\text { 2009; (32) }\end{array}$ & 1 & 2 & 0 & 1 & 1 & 2 & 2 & 0 & 1 & 2 & 0 & 2 & 14 \\
\hline $\begin{array}{l}\text { Zeng et al. } \\
\text { 2014; (33) }\end{array}$ & 2 & 2 & 0 & 1 & 1 & 1 & 2 & 0 & 2 & 2 & 1 & 2 & 16 \\
\hline Zeng et al. & 2 & 2 & 0 & 1 & 1 & 2 & 2 & 0 & 1 & 2 & 1 & 2 & 16 \\
\hline
\end{tabular}

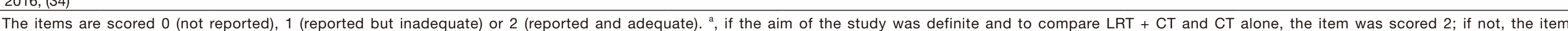

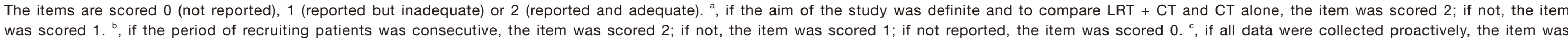

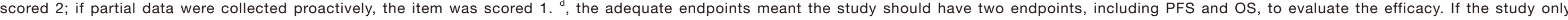

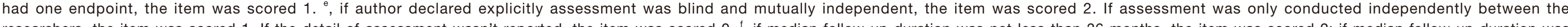

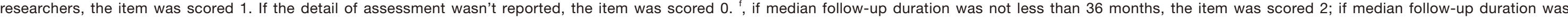

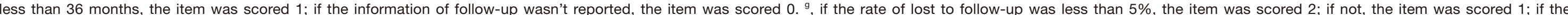

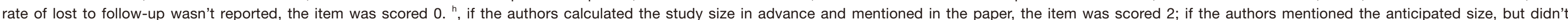

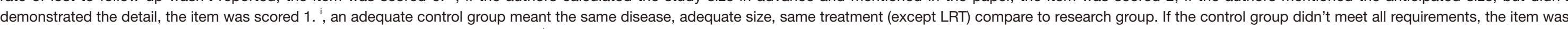

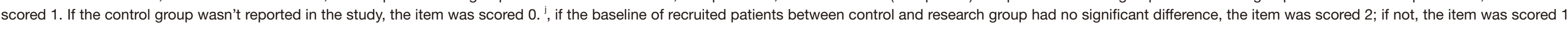
if the baseline wasn't reported, the item was scored 0 . 
Hazard Ratio Hazard Ratio

Study or Subgroup log[Hazard Ratio] SE Weight IV. Random, 95\% Cl IV. Random, $95 \% \mathrm{Cl}$

2.1.1 all patients had single metastatic organ

Chen 2018

$\begin{array}{ll}-0.93 & 0.32\end{array}$

Lu T 2016

$\begin{array}{ll}-0.71 & 0.33\end{array}$

$5.2 \%$

Ma J 2010

$\begin{array}{ll}-0.97 & 0.4\end{array}$

$5.0 \%$

Sun XS 2019

$-0.73 \quad 0.23$

$3.8 \%$

$\begin{array}{lll}-1.5 & 0.56 & 2.2 \%\end{array}$

Xu 2011

Subtotal $(\mathbf{9 5 \%} \mathrm{Cl})$

$0.39[0.21,0.74]$

$0.49[0.26,0.94]$

$0.38[0.17,0.83]$

$0.48[0.31,0.76]$

$0.22[0.07,0.67]$

Heterogeneity: $\mathrm{Tau}^{2}=0.00 ; \mathrm{Chi}^{2}=1.95, \mathrm{df}=4(\mathrm{P}=0.74) ; \mathrm{I}^{2}=0 \%$

Test for overall effect: $Z=5.85(P<0.00001)$

\subsection{2 not all patients had single metastatic organ}

\begin{tabular}{|c|c|c|c|c|}
\hline Chen 2013 & -0.93 & 0.13 & $12.1 \%$ & $0.39[0.31,0.51]$ \\
\hline Huang T 2020 & -0.92 & 0.13 & $12.1 \%$ & $0.40[0.31,0.51]$ \\
\hline Hui L 2013 & -1.08 & 0.18 & $9.8 \%$ & $0.34[0.24,0.48]$ \\
\hline Sun 2019 & -0.27 & 0.13 & $12.1 \%$ & $0.76[0.59,0.98]$ \\
\hline Tian YH 2016 & -0.46 & 0.19 & $9.4 \%$ & $0.63[0.44,0.92]$ \\
\hline Wang CT 2019 & -0.6 & 0.37 & $4.3 \%$ & $0.55[0.27,1.13]$ \\
\hline Zeng L 2014 & -0.73 & 0.18 & $9.8 \%$ & $0.48[0.34,0.69]$ \\
\hline Zheng W 2016 & -0.53 & 0.28 & $6.2 \%$ & $0.59[0.34,1.02]$ \\
\hline Subtotal $(95 \% \mathrm{Cl})$ & & & $75.9 \%$ & $0.49[0.39,0.62]$ \\
\hline
\end{tabular}

\subsection{3 unknown}

Pan Y 2018

$-0.3 \quad 0.25$

Not estimable

Subtotal $(\mathbf{9 5} \% \mathrm{Cl})$

Not estimable

Heterogeneity: Not applicable

Test for overall effect: Not applicable

Total $(95 \% \mathrm{Cl})$

$100.0 \% \quad 0.47[0.40,0.56]$

Heterogeneity: Tau $^{2}=0.05 ; \mathrm{Chi}^{2}=26.10, \mathrm{df}=12(\mathrm{P}=0.01) ; \mathrm{I}^{2}=54 \%$

Test for overall effect: $Z=8.41$ ( $P<0.00001$ )

Test for subaroun differences: $\mathrm{Chi}^{2}=0.63 . \mathrm{df}=1(\mathrm{P}=0.43) . \mathrm{I}^{2}=0 \%$
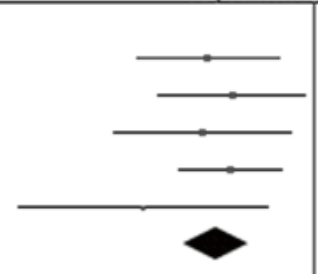

Figure S2 Forest plots of subgroup analysis according to single metastatic organ. 
Hazard Ratio

Study or Subgroup log[Hazard Ratio] SE Weight IV. Random, 95\% Cl

2.3.2 partial patients received local treatment

Chen 2013

Chen 2018

Huang T 2020

Lu T 2016

Ma J 2010

Sun XS 2019

Tian YH 2016

Wang CT 2019

Zheng $W 2016$

Subtotal $(95 \% \mathrm{CI})$

Heterogeneity: $\mathrm{Tau}^{2}=0.00 ; \mathrm{Chi}^{2}=6.79, \mathrm{df}=8(\mathrm{P}=0.56) ; \mathrm{I}^{2}=0 \%$

Test for overall effect: $Z=11.64$ ( $P<0.00001$ )

\subsection{3 no patient received local treatment}

Hui L 2013

Pan Y 2018

Sun 2019

Xu 2011

Zeng L 2014

Subtotal $(\mathbf{9 5} \% \mathrm{Cl})$

Heterogeneity: $\operatorname{Tau}^{2}=0.14 ; \mathrm{Chi}^{2}=18.05, \mathrm{df}=4(\mathrm{P}=0.001) ; \mathrm{I}^{2}=78 \%$

Test for overall effect: $Z=3.39(P=0.0007)$

\section{Total $(\mathbf{9 5} \% \mathrm{CI})$}

$-1.08 \quad 0.18$

$\begin{array}{ll}-0.3 & 0.25\end{array}$

$\begin{array}{lll}-0.27 & 0.13\end{array}$

$\begin{array}{ll}-1.5 & 0.56\end{array}$

$-0.73 \quad 0.18$

$9.1 \%$
$6.7 \%$
$11.2 \%$

$2.1 \%$

$9.1 \%$

$38.2 \%$

$0.34[0.24,0.48]$

$0.74[0.45,1.21]$

$0.76[0.59,0.98]$

$0.22[0.07,0.67]$

$0.48[0.34,0.69]$

$0.51[0.34,0.75]$

$0.39[0.31,0.51]$

$0.39[0.21,0.74]$

$0.40[0.31,0.51]$

$0.49[0.26,0.94]$

$0.48[0.31,0.76]$

$0.63[0.44,0.92]$

$0.55[0.27,1.13]$

$0.59[0.34,1.02]$

$0.45[0.39,0.51]$

Heterogeneity

Test for overall effect: $Z=8.21(P<0.00001)$

Test for subaroun differences: $\mathrm{Chi}^{2}=0.35 . \mathrm{df}=1(\mathrm{P}=0.55) . \mathrm{I}^{2}=0 \%$

Figure S3 Forest plots of subgroup analysis according to local treatment.
Hazard Ratio

IV. Random, 95\% Cl

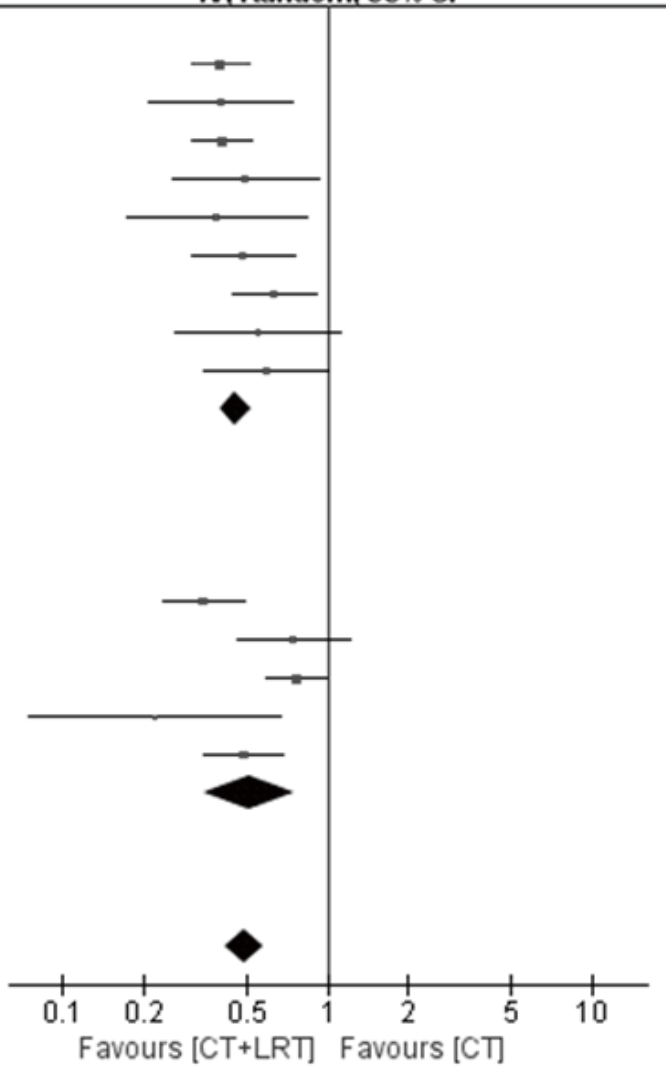


Hazard Ratio

Study or Subgroup log[Hazard Ratio] SE Weight IV, Random, $95 \% \mathrm{Cl}$

2.4.1 recruitment period earlier than 2010

Chen 2013

Chen 2018

Hui L 2013

Lu T 2016

Ma J 2010

Sun XS 2019

Tian YH 2016

Wang CT 2019

Xu 2011

Zeng L 2014

Zheng W 2016

Subtotal $(\mathbf{9 5} \% \mathrm{Cl})$ $\begin{array}{ll}-0.93 & 0.13\end{array}$

$\begin{array}{lll}-1.08 & 0.18 & 9.1 \%\end{array}$

$\begin{array}{lll}-0.71 & 0.33 \quad 4.8 \%\end{array}$

$\begin{array}{lll}-0.97 & 0.4 & 3.6 \%\end{array}$

$\begin{array}{lll}-0.73 & 0.23 \quad 7.3 \%\end{array}$

$\begin{array}{lll}-0.46 & 0.19 & 8.7 \%\end{array}$

$\begin{array}{lll}-0.6 & 0.37 & 4.1 \%\end{array}$

$\begin{array}{lll}-1.5 & 0.56 \quad 2.1 \%\end{array}$

$\begin{array}{lll}-0.73 & 0.18 & 9.1 \%\end{array}$

$-0.53 \quad 0.28 \quad 5.9 \%$

$70.9 \%$
$0.39[0.31,0.51]$

$0.39[0.21,0.74]$

$0.34[0.24,0.48]$

$0.49[0.26,0.94]$

$0.38[0.17,0.83]$

$0.48[0.31,0.76]$

$0.63[0.44,0.92]$

$0.55[0.27,1.13]$

$0.22[0.07,0.67]$

$0.48[0.34,0.69]$

$0.59[0.34,1.02]$

0.44 [0.39, 0.51$]$
Heterogeneity: Tau $^{2}=0.00 ; \mathrm{Chi}^{2}=10.05, \mathrm{df}=10(\mathrm{P}=0.44) ; \mathrm{I}^{2}=0 \%$

Test for overall effect: $Z=11.86(P<0.00001)$

\subsection{2 recruitment period later than 2010}

Huang T 2020

Pan $Y 2018$

Sun 2019

Subtotal $(95 \% \mathrm{Cl})$

$\begin{array}{rrr}-0.92 & 0.13 & 11.2 \% \\ -0.3 & 0.25 & 6.7 \% \\ -0.27 & 0.13 & 11.2 \% \\ & & 29.1 \%\end{array}$

$0.40[0.31,0.51]$

$0.74[0.45,1.21]$

$0.76[0.59,0.98]$

$0.60[0.37,0.96]$

Heterogeneity: $\operatorname{Tau}^{2}=0.15 ; \mathrm{Chi}^{2}=13.73, \mathrm{df}=2(\mathrm{P}=0.001) ; \mathrm{I}^{2}=85 \%$

Test for overall effect: $Z=2.12(P=0.03)$

\section{Total $(\mathbf{9 5} \% \mathrm{Cl})$}

Heterogeneity: Tau $^{2}=0.05 ; \mathrm{Chi}^{2}=28.98, \mathrm{df}=13(\mathrm{P}=0.007) ; \mathrm{I}^{2}=55 \%$

Test for overall effect: $Z=8.21$ ( $P<0.00001$ )

Test for subaroun differences: $\mathrm{Chi}^{2}=1.40 . \mathrm{df}=1(\mathrm{P}=0.24) . \mathrm{I}^{2}=28.8 \%$
Hazard Ratio

IV. Random, 95\% Cl

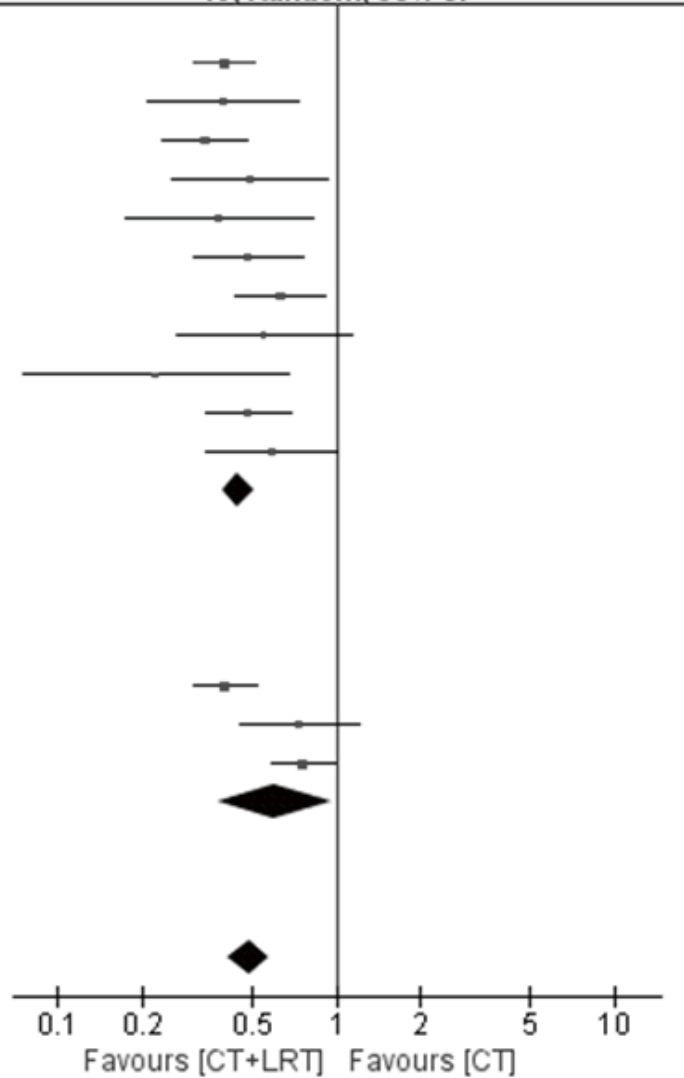

Figure S4 Forest plots of subgroup analysis according to recruitment period. 